\title{
The Role of Cultural Routes in Sustainable Tourism Development: A Case Study of Syria's Spiritual Route
}

\author{
Bashar Dayoub ${ }^{1,3^{*}}$, Peifeng Yang ${ }^{1}$, Alaa Dayoub ${ }^{2}$, Sarah Omran $^{1}, \mathrm{He} \mathrm{Li}^{1}$ \\ ${ }^{1}$ Af1Faculty of Architecture and Urban Planning/ Key Laboratory of New Technology for Construction of Cities in Mountain \\ Area, Ministry of Education, Chongqing University, Chongqing 400045, China \\ ${ }^{2}$ College of Economic and Business Administration, Chongqing University, Chongqing 400044, China \\ ${ }^{3}$ Faculty of Architectural Engineering, Tishreen University, Latakia, Syria
}

Corresponding Author Email: bashar.dayoub@hotmail.com

https://doi.org/10.18280/ijsdp.150610

Received: 13 December 2018

Accepted: 20 December 2019

\section{Keywords:}

cultural tourism, cultural routes, cultural corridors, tourism destination, the spiritual route, creative tourism, slow tourism, sustainability, sustainable tourism, SWOT analysis

\begin{abstract}
Cultural routes and associated cultural tourism are innovative, broadly networked, and designed tourism systems that serve multiple purposes. Cultural routes had become a tool for maintaining destinations and promoting tourism simultaneously. This study assesses the potential of cultural routes in rebuilding Syria's dire tourism infrastructure situation after the war. The aim is to examine whether the "Spiritual Route" proposed by the Syrian Ministry of Tourism has the potential to attract tourists and reinstate itself as a sustainable route generating benefits for all stakeholders. The purpose is to determine the potential the "Spiritual Route" has for tourism and how it may attract people. Data has been obtained from a literature review and reconstructed from interviews and information from tourism databases and concerned personnel on its history, geography, and potential as a sustainable culture. The results from a SWOT analysis and the literature review revealed that the "Spiritual Route" has the potential to become a primary tourism attraction for a wide audience. This can be achieved by linking the tangible heritages of different geographical areas if planning and development are appropriate; however, the current internal situation of the war is a substantial hindrance. These principal findings can contribute as a valuable review in highlighting key limitations to be dealt with by decision-makers of Syria's "Spiritual Route" and others working on similar cultural routes in post-war Syria.
\end{abstract}

\section{INTRODUCTION}

The cultural route has a huge potential for cultural tourism [1]. In the 19th century, members of the British aristocracy frequently made a "Grand Tour" of continental Europe. They visited places of high civilization: Egypt, Syria, Greece, Italy, to enrich their outlook [2]. Cultural tourists travel to other states and communities to learn about cultures. But this learning process is usually negative [3]. Cultural tourism isn't confined to simply sightseeing. The route is systematically broken down into an interlinked web of cohesive sites [4]. "Cultural Routes" illustrates and enriches the growing trend of a cultural heritage approach through a multidimensional impression and contributes to our knowledge [2]. The Council of Europe's cultural routes program launched the Saint James Pilgrimage Ways as the first Council of Europe cultural route. They have recognized the cultural routes since 1987 [5]. Syria has a diverse and rich cultural heritage, as well as famous sites dating back to early Christianity and the Byzantine period to the Islamic and Ottoman Empires. Pre-war, the tourism sector in Syria employed $20 \%$ of the population. Syria has around 3,000 archaeological and cultural sites, which are barely promoted $[6,7]$. They include some of the oldest and most prestigious sites in the world [8]. Syria is a valuable asset for archeologists owing to ancient cities like Aleppo and Damascus. They are recognized as UNESCO's World Heritage
Cities [9]. The war in Syria has resulted in chaos. Critical conditions in Hama and Homs have severely affected the roads between Aleppo and Damascus and most of the UNESCO World Heritage Sites in Syria have suffered [10].

Cultural tourism may help in improving Syria's image after the war. The promotion of Syrian cultural routes can promote tourism growth with an emphasis on remote sites with extensive coverage. This study aims to analyze the potential of the proposed "Spiritual Route" by the Ministry of Tourism in Syria as a productive cultural route. The research examines whether this route will act as a sufficient source for sustainable development serving multiple causes. This study also investigates the route's capacity to serve various purposes including economic development, post-war rehabilitation for residents of these routes, and cultural promotion, and its capability to act as a new tool for sustainable tourism development. Finally, the findings aim to identify the key steps and approaches required for sustainable tourism routes development.

\section{LITERATURE REVIEW}

Culture and tourism are interlinked to serve the main objective of representing the past to the present [11]. Accordingly, cultural routes provide a connection with both 
intangible and tangible heritage to attract the present generation of the "new tourism," which is emerging from cultural tourism. This new type of tourism that the cultural routes belong to is known as "creative tourism" [12]. Cultural Routes not only delivers creative activities and learning the medium, but they also maintain sustainable tourism [13].

Creative tourism can be defined as experiencing local culture by performing and participating in activities related to that culture. The activities can be associated with arts, religious offerings, or even eating the local food [14]. Creative tourism has become increasingly important to support the identity of the destination site and to stimulate the consumption of local culture and creativity [15]. In creative tourism, a cultural route has to function as a cultural tourism product as well as by having all necessary product features and offering corresponding content, information, and facilities for providing hospitality and accommodation services [5]. Richards is known for his recognition of the emerging creative tourism as the new and more interactive cultural tourism [16]. Richards and Raymond further elaborated that creative tourism enhances public engagement [17]. Tourism designed around creativity generally produces more revenue than traditional cultural tourism [15].

The next important approach is "slow tourism" and its integration and effective role in promoting a creative form of cultural tourism. Slow tourism is a form of tourism which emphasizes experiencing a journey without complications, rushing, or discomforts. This type of tourism promotes a slower approach to discover and enjoy every aspect of the tour in a planned manner. One of the major issues associated with tourism currently is the stress associated with covering too many distant sites in a short time [18]. Cultural routes have the potential to integrate slow tourism while covering multiple destinations and engaging tourists.

The Council of Europe is developing a "Cultural Corridor" scheme. The intent is to create networks that transcend the tangible routes interlinking cultural sites. These corridors will accommodate the entire variety of creative assets in a region. A tourist can experience them at a slow pace without being rushed owing to physical separation [19]. According to ICOMOS and its International Committee on Cultural Routes, key features of the cultural route such as the integration of economic and spiritual aspects of a site, cultural itinerary, and history of the route itself are important [20]. Cultural corridors and routes are an attractive solution to give travelers an opportunity for extensive exposure along a themed route [21]. The cultural corridors are of two types: those interconnecting primary and secondary sites to form a cultural itinerary and those presenting corridors themselves as the destination [22]. Apart from a role in economic development, tourism routes are also important tools for environmental conservation and managing the human impact on such sites [23, 24]. Thus, cultural routes can act as a sustainable development tool for marginal or rural areas capitalization and establishment [25]. Syria currently faces fragmented tourism, but new approaches to international tourism are now being considered to contribute to the local budget [26, 27].

\section{RESEARCH METHODOLOGY}

\subsection{Study area}

The study area appointed for this study is four integrated routes situated in Syria. These include four transnational cultural routes: the Abraham Path, the Way of St. Paul from Jerusalem to Rome, the Way of Ahlul Bayt from Karbala to Damascus, and the Pilgrimage Route from Istanbul to Mecca ("The Hajj Route"). These paths are interlinked with several cities, towns, villages, and communities across the Middle East, including Syria. It is vital to understand the reason behind the selection of this study area and to highlight the significance of the ancient roads [28]. However, to identify a sustainable cultural route in this study, the theme for its development is specified. The theme links the paths and their potential appeal for external visitors [29].

\subsection{Data collection}

The data were collected from different sources: the Syrian Ministry of Tourism website and related websites, observation and discussions with officials and key tourism administrators, etc. In addition, data were collected by visiting some of the same areas during the preparation of the undergraduate project entitled "Return of the Spirit to the Route of St. Maron" in 2010. Tourism authorities provided data on tourism based on a police database of arrival and departure of foreign and Syrian citizens but have no records of tourist accommodations and purpose of visit.

\subsection{Data analysis}

To devise a systematic approach for essentials in design and maintenance, the directives derived from the literature were applied to the case-study "Spiritual Route," and a SWOT analysis was performed. The application of a case-study approach is considered to provide a rigorous investigation into the limitations and strengths of this plan [30]. The data organized through primary and secondary research and literature recommendations provide a list of approaches essential to the successful implementation of the "Spiritual Route" project.

\subsection{Limitations}

Limitations in the implementation of this program by Syria arise because several areas along the "Spiritual Route" are still outside the control of the Syrian government. Therefore, it is problematic to evaluate the condition of archaeological and historical sites in those areas.

\section{PLANNING A SUSTAINABLE CULTURAL ROUTE}

The first key factor of a thematic route is the area's attractions structure [31]. Thematic routes are attached to attractions organically tied to the geographical space, thus integrating creative and slow tourism in the process. This category launches the model of a new type of heritage. The cultural route illustrates the contemporary design of the values of heritage for the private and public sector stakeholder organizations as a resource of sustainable social and economic development [25]. Rural communities are entwined in this process using three strategies to promote economic growth. These include place-based development, economic gardening, and cultivating creativity. Collaboration can also contribute to reaching the aim of sustainability, primarily through its integrative approach [32]. The clustering of activities in less 
developed areas stimulates cooperation in local and neighbouring regions and promotes economic development through tourism [28]. Sustainable rural tourism thrives through local cooperation [33]. These itineraries have the potential to enhance a region's attractiveness and competitiveness from both a cultural and tourism point of view [34]. Based on the UNWTO/ETC Handbook on Product Development, the role of tourism routes in fostering regional development and trans-boundary cooperation is evident. This is due to large area coverage, heritage conservation, source of emotional bonding, and a marketable approach to provide mutual benefits to visitors and local residents. Essentially, sustainable development is enabled through revenue generation, enhanced tourist frequency and length of stay, and heritage maintenance [35]. Nonetheless, planning and developing a cultural route is a rather complicated and challenging process. Suggestions are provided by López Fernández $[29,36]$ in Table 1.

Cooperation and collaboration among the different actors involved in a cultural route are also key to ensure the overall accessibility of an itinerary. Tourism services and facilities need to be accessible to visitors, and the staff employed in these services needs to be trained [29, 37]. The accessibility of an itinerary includes transportation and information. Thus tools like online platforms for the tourist to get assistance are crucial [38-40]. The Council of Europe mentions a list of sustainable development indicators in Table $2[29,41]$.

Table 1. Elements to take into account in the development of a cultural route (Source: López Fernández 2006)

\begin{tabular}{cc}
\hline Indicator & Specific measuring instruments \\
\hline Justification & A valid reason for the development \\
Main goal & Clear vision devised by decision-makers \\
Objectives or sub-goals & Measurable objectives defined \\
Inventory of the assets & Planners need to list the assets \\
Market potential & Determine attractiveness, target group and impact on the economy \\
Designing itinerary & Accessibility, integration of assets, documentation, route stops and time division, opening date for the \\
& itinerary, funding, logo, commercialization of itinerary and monitoring/evaluation \\
\hline
\end{tabular}

Table 2. Indicators of Socio-Economic and Environmental Sustainability for Cultural Routes (Source: Fundamental indicators of sustainable tourism (WTO, 1997))

\begin{tabular}{cc}
\hline Indicator & Specific measuring instruments \\
\hline Site management & Categorized index for site protection by IUCN \\
Utilization Intensity & Frequency of tourists \\
Social impact & Usage during high tourist load \\
Development control & Tourists and residents proportion \\
Waste management & Control over management and usage \\
Planning & Wastewater treatment ratio \\
Fragile ecosystems & A systematic plan for tourist destination \\
Consumer satisfaction & Endangered ecosystem management \\
The Satisfaction of inhabitants & Tourist satisfaction level \\
Local economy profits & Residents satisfaction level \\
Carrying capacity & Revenue generated via tourism \\
Site disturbance & The ability of the site to cope with tourism intensity \\
Interest & Impact levels on the site \\
Customer satisfaction & Attractive features of tourism site \\
& Survey score \\
\hline
\end{tabular}

\section{THE HISTORICAL ROUTES WHICH FORM THE "SPIRITUAL ROUTE"}

The movement of individuals or groups from their original location towards places considered "sacred" is common in human history [28]. The proposed "Spiritual Route" aims to assist people in rediscovering the roots of the Syrian and Middle Eastern culture by following the footsteps of "Abraham," "St. Peter", "Ahlul Bayt" and the "Hajj Route.

\subsection{Abraham path}

The Jewish religion emerged in ancient times. Christianity grew in the first century AD and Islam in the seventh century AD. These "desert religions" are called "Abrahamic Religions" after the Prophet Abraham [42]. Abraham/Ibrahim is the father of monotheistic religions [43]. The Abraham Path is a walking path (Figure 1a) that follows the historic route of Abraham 4000 years ago through the Fertile Crescent, the
Arabian Peninsula, and the Nile Valley. His journey resulted in a spiritual tradition followed by nearly three billion people presently [44]. The key idea for this path is to develop ties among Middle Eastern communities and foreigners [45] through stories, walking together, and hospitality along the ancient path of Abraham [46]. The path represents an innovative approach for tourism and peacebuilding [43].

\subsection{St. Paul's Journey}

St. Paul was considered the foundation of the Church and the Prince of the Apostles. The pilgrims in many local traditions share the memory of his passage to Rome from the Holy Land. This route links the most important sites of Christian origin [28]. The Apostles, led by St. Paul, published their Gospel to non-Jewish nations in the first century AD (Figure 1b). The Romans transferred the slaves captured in the Jewish revolt (66-73 AD) throughout their empire and Christianity spread with them. Christians built their churches 
to look like houses [42].

\subsection{The journey of Ahlul Bayt from Karbala to Damascus}

In $685 \mathrm{AD}$, the Ahlul Bayt were sent to Syria, on orders of Yazid [47]. The caravan passed through several sites on its way to Damascus. [48]. There are three routes from Kufa to Damascus; the most famous route is Sultani, which is 1545 kilometers long and passes through various cities like Mosul,

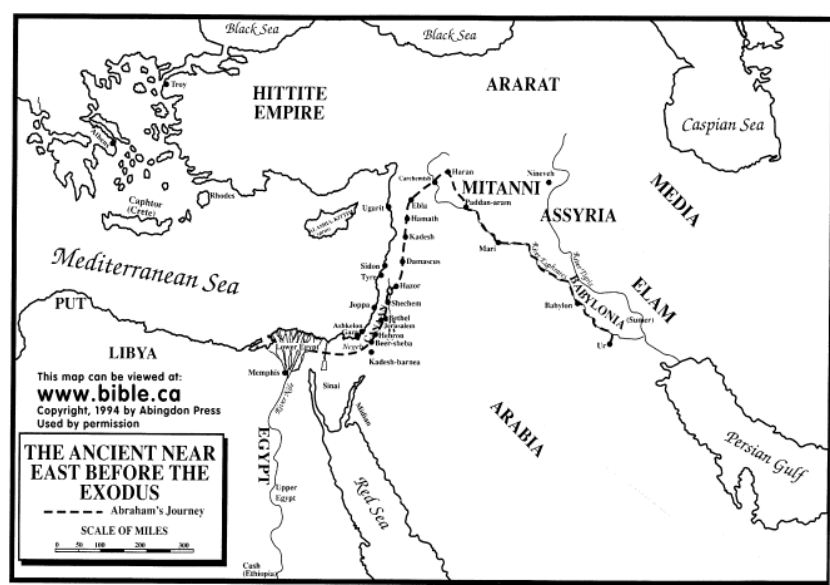

(a) Abraham's journey from Ur to Canaan. (Source: wikichristian.org.)

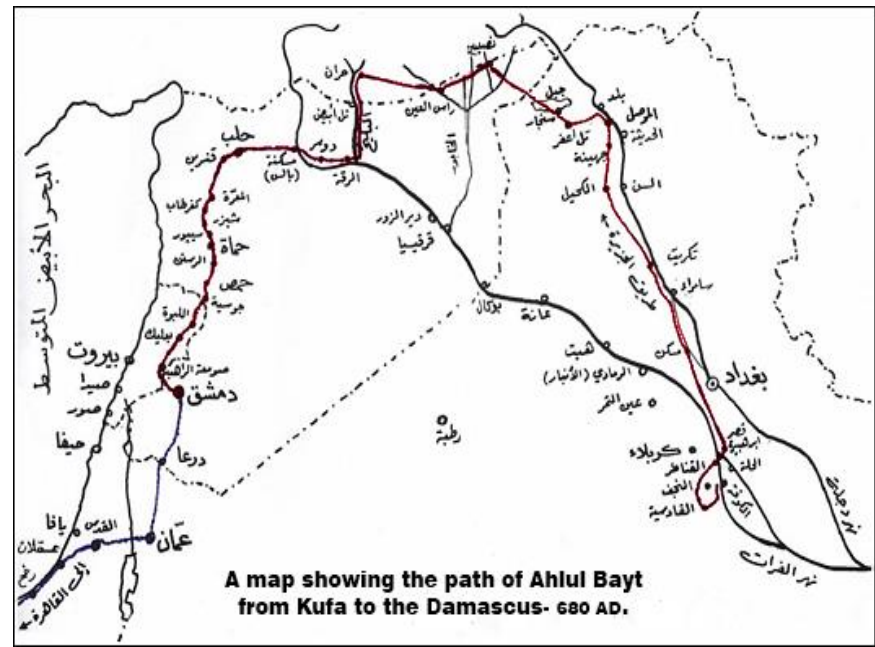

(c) The journey of Ahlul Bayt from Kufa to Damascus. (Source: alhikmeh.org.
Nasibiyen, and Aleppo. Today, this route (Figure 1c), passes through several countries [49]. Wherever the head of Imam Husain reached, and after each bold speech by Imam Sajjad and Janabe Zainab after Ashura, people would cry [49]. The journey from Kufa to Damascus took over twenty days. The children and women suffered greatly at this time because of the duration. This is why the route had a large number of small graves [50].

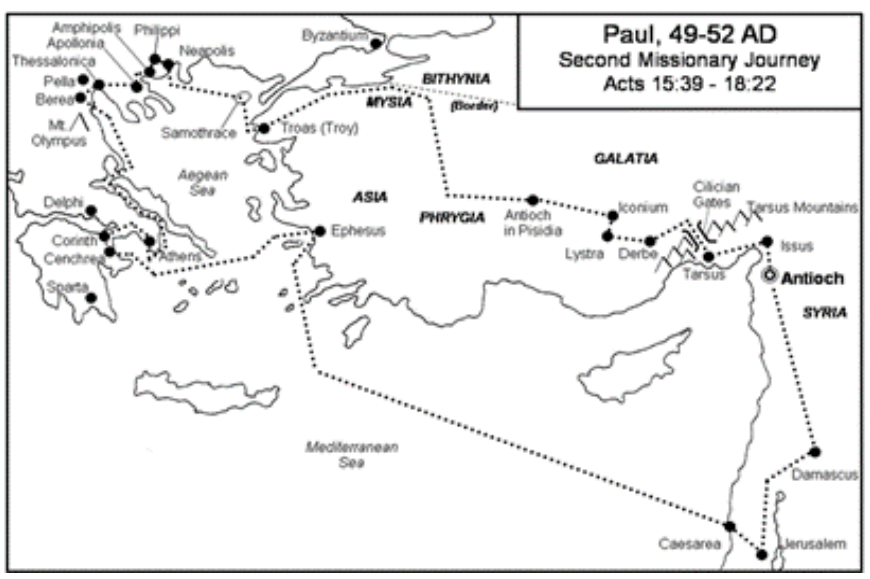

(b) Paul's journey from Canaan to Rome. (Source: generationword.com.)

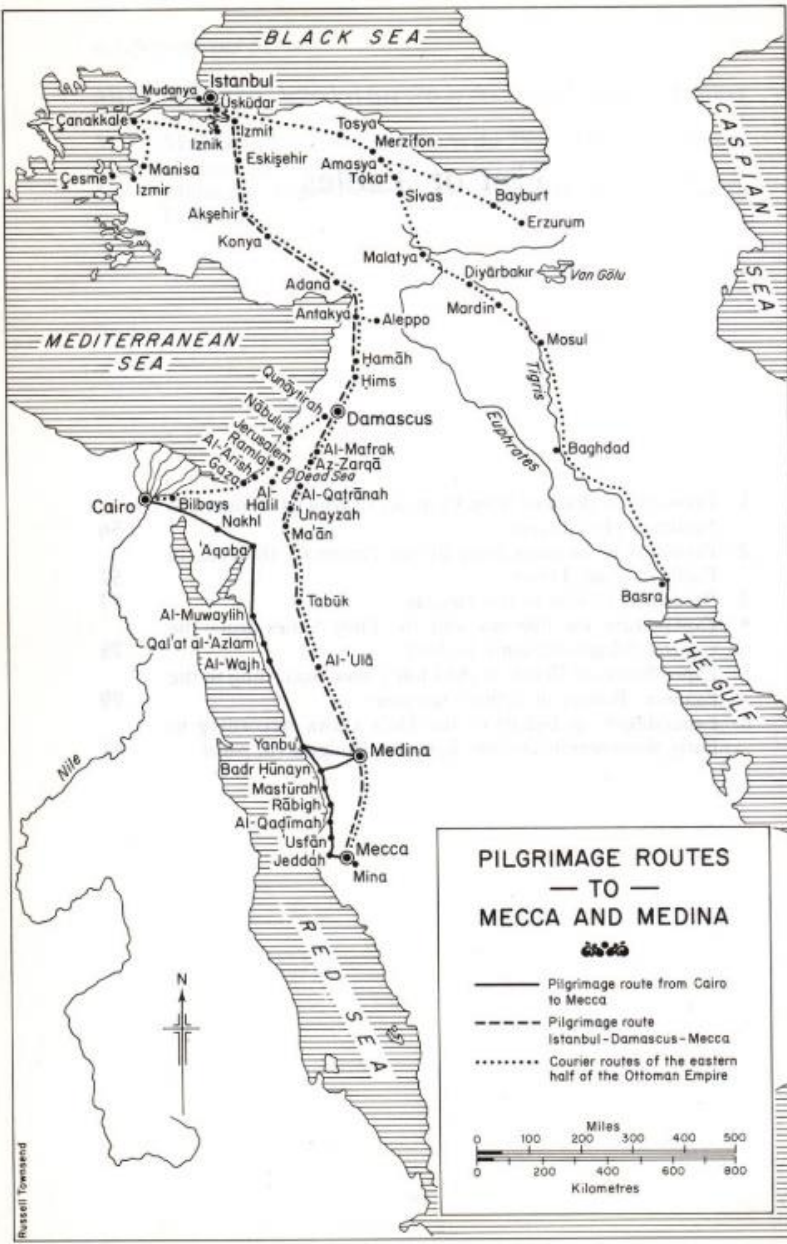

(d) Pilgrimage Route from Istanbul to Meca. (Source: mediterraneannetworks.weebly.com.)

Figure 1. Map of the regions of the "Spiritual Route" through the cities of Syria, including Damascus and Aleppo 


\subsection{Pilgrimage Route to Mecca and Medina "The Hajj Route"}

The Prophet Muhammad had led the Hajj in 632, the year of his death. Hajj now attracts nearly three million pilgrims each year. Going on a pilgrimage is a spiritual effort that starts at the pilgrim's home and is completed in Mecca. Hajj is done at a specific time, so pilgrims move in convoys [51]. By 1517, the Ottomans assumed responsibility for the pilgrimage. They controlled the holy cities, Hijaz, and used their resources for protecting caravans, maintaining roads, and taking care of sacred shrines in Medina and Mecca. Those traveling on foot congregate at three points: Cairo (Egypt), Damascus (Syria), and Kufa (Iraq) [52] (Figure 1d).

\section{THE "SPIRITUAL ROUTE "AND SUSTAINABLE DEVELOPMENT STRATEGIES}

Table 3. Approach behind the development of the "Spiritual Route" (Source: Created by the authors)

Development of sustainable spiritual route
- Utilization of suitable geographical position and
cultural heritage.
- Pactors
- Reconstruction of Syrian image for improving
international relations
- Creation of a network of tourist destinations in
municipalities crossed by the "Spiritual Route"
- Link national and international markets with the
new tourist destinations
Strategies
- Creation of an integrated tourist offers
-Capitalizing the spiritual attraction for
sustainable tourism development
- Creative and slow tourism for the modern world
- Investment by stakeholders
- Involvement of local community
Shortcomings
- Lack of jurisdiction on certain sites included in
the "Spiritual Route"
- Post-war reconstruction management

The "Spiritual Route" plans to intervene strategically, activating synergies (Table 3 ), to build a unique network of sustainable tourism destinations. All these sites, linked in a network, increase the multiplier effect related to the economic benefits.

The "Spiritual Route" aims to incorporate a sustainable development strategy, which starts from the potential of the area and the creation of new skills and professionalism. It promotes local actors, services, and peculiarities of each municipality crossed by the "Spiritual Route. The intention is to produce: tourism offers, economic and "slow" integrated mobility, and quality and responsive services to meet the needs of tourists and the local population. Contemporary interest in the ecological role of indigenous peoples contributes to the modern management of local ecosystems [53]. Sustainable development is possible by creating interaction between cultural identities, while considering the current economy. Table 4 shows the strengths, weaknesses, opportunities, and threats to identify the current position of the "Spiritual Route" and the potential of this route to create sustainable tourism. It also provides the necessary analysis to know the possibilities of planning the "Spiritual Route" and the obstacles to its implementation.

\section{PLANNING THE "SPIRITUAL ROUTE"}

The "Spiritual Route" highlights some of the similarities in the established acts and the sites that the local stories have described. Historical sites and sources generally refer to the existence of a shrine, crypt, a rock-cut church, sanctuary, marabout, or a ravine. The Prophets, Apostles, and Saints performed miracles, celebrated masses, stirred peoples' emotions and, at times, converted them to the new religion. It also highlights the recurrence of underground sites and the water sources in some regions. It describes the mountain tops and the aspects of modern devotional practice that link the rituals and customs of these areas.

Other choices were based upon the optimal investment of the old cities. Examples of this tradition include the cities of Damascus, Homs, Hama, Aleppo, etc. In these places, the incidents of the blessed people occurred, and their itineraries had passed through these cities. Almost all sites along the "Spiritual Road" are located near villages, rivers, major highways, and sometimes remote areas. Many of these sites are outside the urban environment, which is easily accessible from towns and villages.

Table 4. SWOT analysis (Source: Created by the authors)

\begin{tabular}{|c|c|}
\hline Strengths & $\begin{array}{l}\text { - Rich and diverse natural and cultural heritage resources. } \\
\text { - A growing contribution to the GDP and providing new and growing job opportunities. } \\
\text { - The existence of a cultural and civilization heritage, and the enormous potential of tourism are considered as an untapped } \\
\text { wealth of culture, history, cultural diversity, and nature. } \\
\text { - The variety of Syrian tourism products forms an advantage for international tourism. } \\
\text { - The geographical location of Syria close to the biggest exporters of tourists } \\
\text { - The traditions of hospitality and warm guest reception characterized Syrians. }\end{array}$ \\
\hline Weaknesses & $\begin{array}{l}\text {-Lack of private, local tourism bodies and organizational structures. } \\
\text { - The current situation of Syrian tourism is still underdeveloped but which maybe be exploited for potential opportunities in } \\
\text { terms of the number of tourists, the level of investments, and the rate of tourism spending. } \\
\text { - Lack of infrastructure in the tourism sector (public utilities and the number of hotels and restaurants), poor management in } \\
\text { the concerned ministries, tourism chambers, and private offices. } \\
\text { - Reduced demand for local and international tourism as a result of the current war, which has been affecting the sector since } \\
\text { the year } 2011 \text {. } \\
\text { - Data on tourism not appropriately structured. }\end{array}$ \\
\hline
\end{tabular}




\begin{tabular}{|c|l|}
\hline Opportunities & $\begin{array}{l}\text { - A highly diversified product which is an opportunity for multiple linkages. } \\
\text { - Increase in the employment opportunities and the usage of cultural heritage to increase link of the growth of tourism with } \\
\text { other sectors art crafts } \\
\text { - Improve the social, economic and environmental impacts of the tourism development process. } \\
\text { - Promote the values and mechanisms of Syrian hospitality, and promote the local cultural products. } \\
\text { - The use of tourism as a useful tool to achieve balanced regional development and the advancement of the quality of life for } \\
\text { the less developed regions where tourism resources are located. } \\
\text { - The introduction of environment-friendly tourism and its development through a parallel source to other sorts of tourism. } \\
\text { - Facilities to build up a mini-hub (gateway). }\end{array}$ \\
\hline Threats & $\begin{array}{l}\text { - The impact of the political situation on the Syrian tourism path, including international pressure, the current war that } \\
\text { threatens peace in the region and the reluctance of tourists to travel to unsafe areas. } \\
\text { - The negative image from Media that composes an inhibiting factor, as part of the political pressures that have weakened } \\
\text { Syria's tourist image. } \\
\text { - Private sector's investments in tourism infrastructure and the threat of eco-tourism as a result of real estate projects in the } \\
\text { areas of origin. }\end{array}$ \\
\hline
\end{tabular}

It is useful to create a winding route that should be designed to link different historical and natural sites. The route mainly lies within the territory between Damascus and Aleppo. In this route, almost all of the sites surveyed are concentrated. However, this route is designed to connect the extra-regional sites through the dense network of cultural and religious itineraries. This could be widely promoted throughout the Mediterranean region and also in the Middle East. Figure 2 (below) shows the suggested itinerary of the "Spiritual Route" in the northwest region, the coastal region, the central region, and the greater Damascus region. Along the "Spiritual Route", (see Table 5), there are four of the six UNESCO World Heritage Sites in Syria [54]; (Ancient City of Damascus (1979), Ancient City of Aleppo (1986), Crac des Chevaliers and Qal'at Salah El-Din (2006), and Ancient Villages of Northern Syria (2011)). There are also five of the twelve sites submitted to UNESCO that are on that organization's tentative list [54]; (Noréas de Hama (1999), Ebla (Tell Mardikh) (1999), Apamée (Afamia) (1999), and Maaloula (1999).

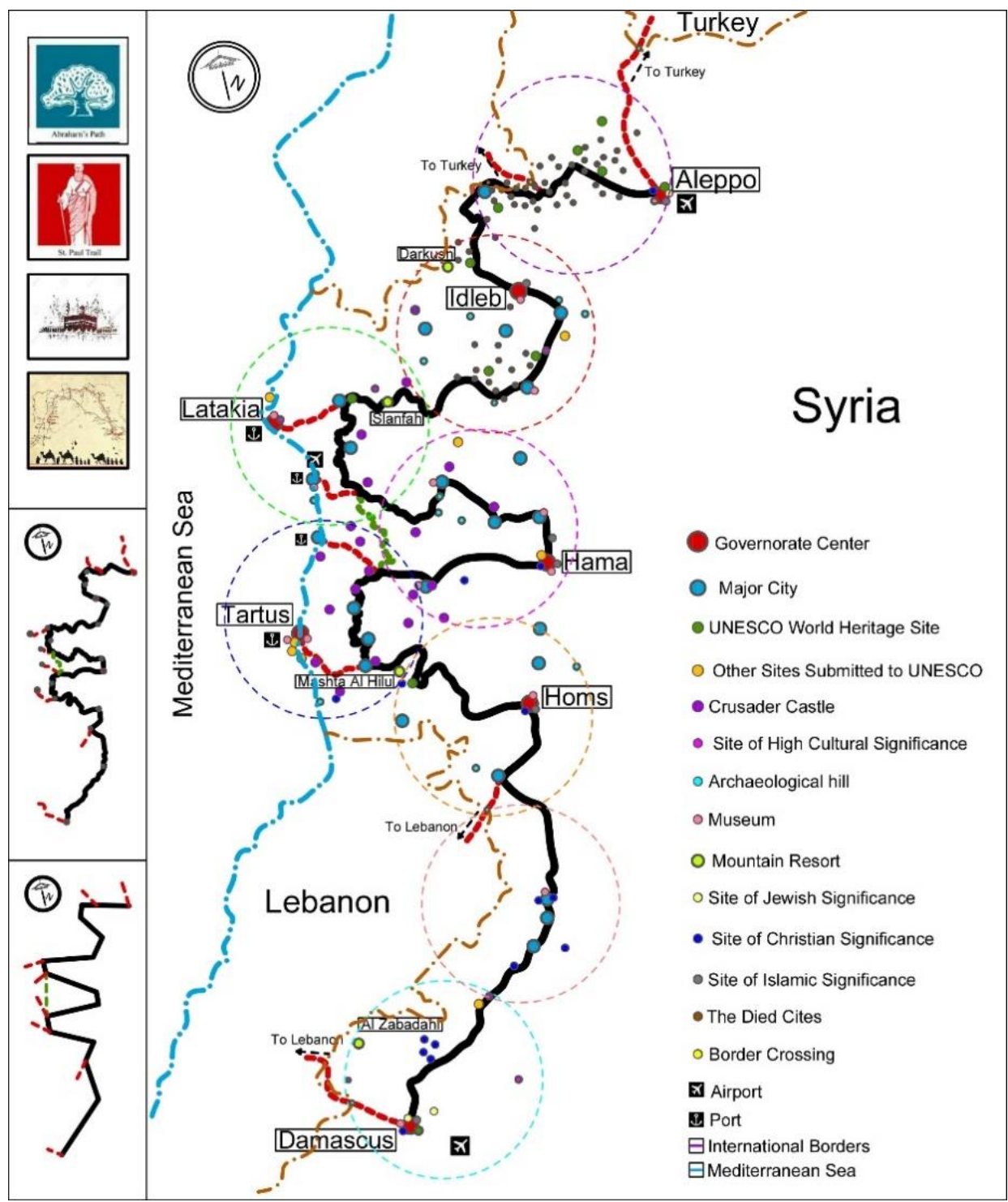

Figure 2. The plan of the "Spiritual Route" between Aleppo and Damascus (Source: Created by the authors) 
Table 5. Tourist locations along the "Spiritual Route" (Source: Personal collection)

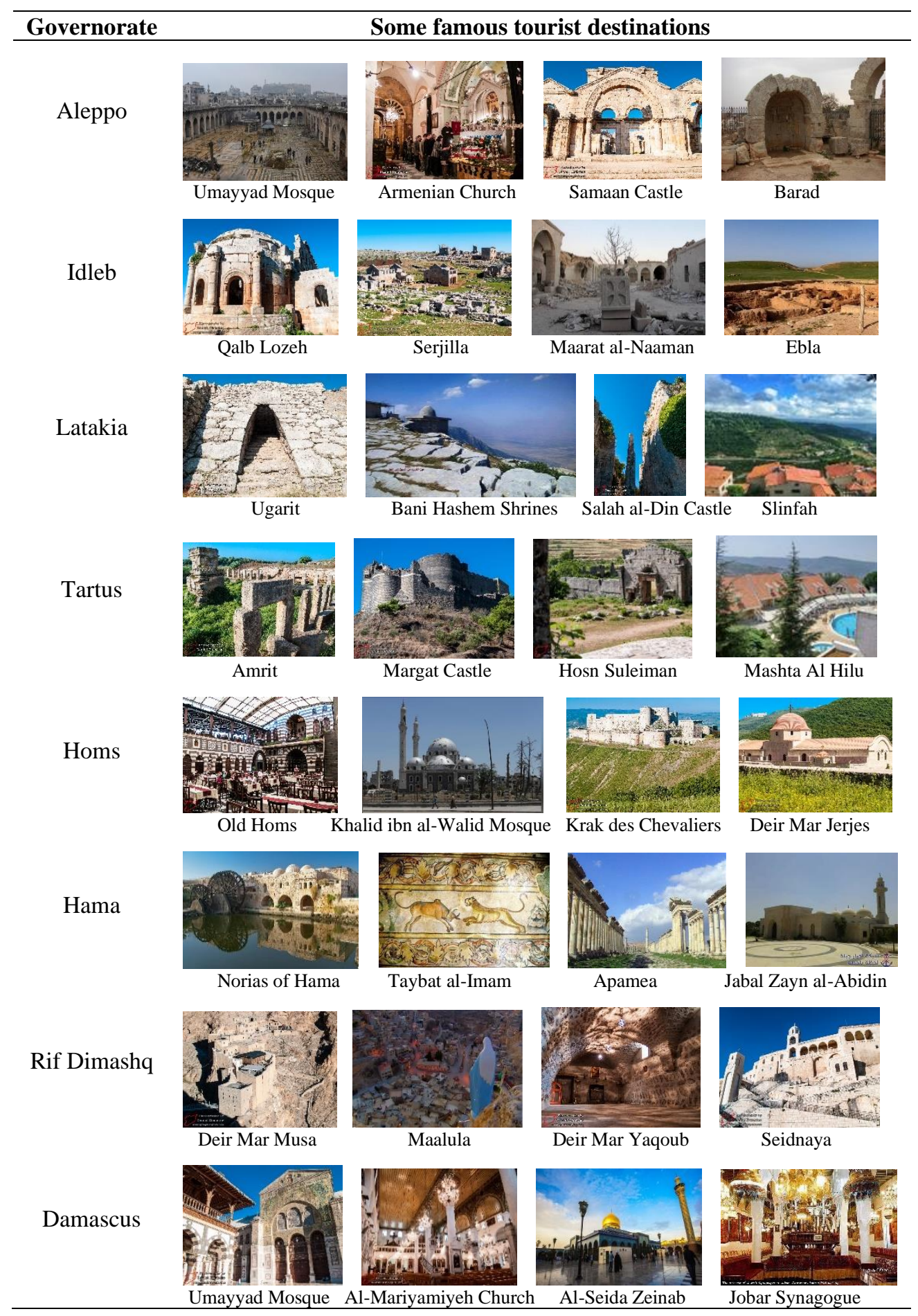

There are many small shrines of a local nature along the route whose attractiveness is linked to the buildings themselves. The surrounding area is a point of reference for local worshipers, celebrators, and those people who enjoy the surrounding landscape. These sites are perhaps unknown even to local inhabitants. In many cases, these elements enjoy a high architectural and artistic value and "tangible" potential as engines of social and economic development when they are "discovered" [55]. The "Spiritual Route" can also depend upon a good and diversified tourism when combined with the religious heritage.

For example, destinations are already present in the Syrian tourism marketplace with a well-reputed tradition of food (like homemade meals by local families, and tea brewed in a kettle over an open flame), as well as a series of events [56]. Many historical sites along the route could also attract visitors from outside the regional area. This diversified offer increases the possibility of these destinations to bring more benefits to the local economy, attract different typologies of visitors, and enrich the overall sustainable tourist experience [29].

Tourists who are already in the area should be directed to visit one of these destinations and can be encouraged to discover the sites of the "Spiritual Route" and their attractions.

Furthermore, to meet the social and economic needs of the host community while maintaining environmental and cultural integrity, travelers should be encouraged to follow this route.

The distinct feature of the "Spiritual Route" theme in the above proposals is that each stage is considered as part of a 
consolidated itinerary [57]. Therefore, to develop this project in the post-war period, it is necessary to produce virtual content and build a uniform communication system that can be accessed by ICT-based systems or by the user at the site [58].

\section{DISCUSSION}

As the conflict in Syria enters its eighth year, this paper focuses on the effectiveness of cultural tourism for the preservation of the Syrian culture. It seeks to find ways to continue to highlight the significance of Syria's history and people. Syria is the main attraction for Europeans in spring and summer, while Gulf tourists mostly visit during summer months. Syria is crossed by a network of itineraries designed for an engaging and immersive regional experience.

In view of the full dimension of the route discussed in this paper, the challenge is to expand it to all the places of the "Abraham Path", "St. Paul Journey", "Journey of Ahlul Bayt", and "Hajj Route". It could also be expanded to include other cultural routes like "Phoenicians' Routes", the "Historical Silk Road", and other ancient Middle East and Mediterranean cities. It can be considered, in this way, as part of the process of cultural integration that is crucial to the future of Syria and the Middle East.

Although the religious connotations of these routes may limit their appeal to non-religious consumers, this concept is a step towards integration and dialogue, which is compatible with the purpose of the "Spiritual Route". It would materially aid in reintroducing Syria as the Cradle of Civilization. This is one of the reasons the "Spiritual Route" is such a unique project. Through urban-rural linkage and increasing the sustainability of the tourism product, the "Spiritual Route" will act as a significant tourism experience. It will remain a useful tool for the reconstruction, restoration, revival, and preservation of heritage sites along this proposed route. Meanwhile, it will be supporting entrepreneurship, improving the local economy, and upgrading the architectural and urban fabric.

In the Syrian post-war period, when the proposed route is further developed, organizers should apply for certification by international organizations like the World Tourism Organization (WTO) and UNESCO World Heritage. As part of this application, an official slogan should be selected for the "Spiritual Route" project. This will stimulate new tools and ideas which will improve the Syrian heritage. But this remains a significant challenge in the context of post-war cultural and local socio-economic developments.

In addition to finances, institutions and stakeholder involvement are crucial at national and international levels to provide visibility to the project [26]. Such collaboration would facilitate identification, documentation, planning, implementation, and promotion of the itinerary. Their participation would be part of the sustainable development of the region and would contribute to the heritage protection process [59].

Furthermore, recognition of the importance of the "Spiritual Route" in Syrian and Middle Eastern history may increase the chances for this itinerary to gain international organizations' cultural route certification. This last objective should be incorporated into the plans of the organizers.

\section{CONCLUSION}

In conclusion, this study finds great potential for Syria in the proposed spiritual route to act as a source of a new form of cultural tourism. This route supports the concept of a creative and slow tourism approach instead of the destinations being a simple visitation site. This is a form of tourism which lends itself to slower types of transportation such as walking and bicycling, in addition to buses and trains. Such tourism presents eco-tourism routes and is capable of merging the promotion of local traditional products with the rediscovery of the environmental and cultural heritage, and enjoying foodand-drink resources, all of which are essential elements of the region's competitiveness and attractiveness. Tourism growth through transnational cultural tourism itineraries will stimulate local investment and economic regeneration of emerging destinations. It further requires improving the integration of social, environmental, and economic factors as complementary rather than conflicting elements. The promotion of creative and slow tourism will be stimulated by experiencing local traditions. The "Spiritual Route" can distribute income from tourism to more marginalized communities. In this context, the impact of the "Spiritual Route" for cultural routes development in Syria could be a positive economic force through the elevation of living standards for local residents as well as a stable, marketable commodity for the government. It will also support a vast SME sector: social in the sense of community involvement, environmentally friendly through responsible use of resources, and maintenance of cultural heritage and providing cultural representation.

Moreover, the "Spiritual Route" could help in recognizing the essential role in bringing peace, thus launching a dialogue of cooperation between Syria and other nations of the world. Planners and actors will need to pay particular attention to elements like theme, geographical setting, tourist services, and accessibility. Creation of the "Spiritual Route" can provide basis for sustainable regional development. The ultimate goal is to create regional narratives that make the traveler connect with the location. In this way, the "Spiritual Route "can develop tourism, promote typical local products, and improve the rural-urban exchange consistent with sustainable development. This study contributes to continuity in research by offering an inventory of potential resources and connecting them into integrated cultural routes. Based on the evaluation of their developmental impact, according to the presented methodological framework, this represents a valuable asset for Syria.

\section{REFERENCES}

[1] Meyer, D. (2004). Tourism Routes and Gateways: Key Issues for the Development of Tourism Routes and Gateways and Their Potential for Pro-Poor Tourism, Overseas Development Institute: London, pp. 1-31.

[2] Majdoub, W. (2009). Cultural Routes: An Innovation Tool for Creative Tourism. Management International Conference - MIC. pp. 1841-1854. (in Tunisia).

[3] Cros, H. (2001). A new model to assist in planning for sustainable cultural heritage tourism. International Journal of Tourism Research, 3(2): 165-170. https://doi.org/10.1002/jtr.297 
[4] Terzić, A., Bjeljac, Ž. (2016). Cultural routes - crossborder tourist destinations within southeastern Europe. Rutele Culturale - Destinatii Turistice Transfrontaliere în Europa de Sud-Est, 15(2): 180-188. https://dx.doi.org/10.5775/fg.2067-

4635.2015.041.dCultural

[5] Cojocariu, S. (2015). The development of cultural routes: A valuable asset for Romania. Procedia Economics and Finance, 32(15): 959-967. https://doi.org/10.1016/S2212-5671(15)01554-3

[6] Strom, C. (2017). Ancient Syria: Another Cradle of Civilization? Ancient Origins. https://www.ancientorigins.net/ancient-places-asia/ancient-syria-anothercradle-civilization-007378, accessed on Oct. 27, 2018.

[7] Cultural Tourism in Syria, AGEG Tourism for Sustainability- European Commission. https://www.ageg-tourism.de/en/projectsreferences.html?id=59, accessed on Sep. 26, 2018.

[8] Nor Eldeen, E. (2018). I was a tour guide in Syria Here's what it was like before the war. The Independent. https://www.independent.co.uk/voices/syria-civil-warbefore-life-assad-regime-tourism-travel-a8317676.html.

[9] Ndongala, B. (2014). No future for Syria's tourism industry. University of Wolverhampton. http://www.travel-

conference.co.uk/commentries.php?paper=222\#.XBIBn HQzbIX, accessed on: 23 Oct. 2018.

[10] Parkinson, J., Albayrak, A., Mavin, D. (2015). Syrian 'monuments men' race to protect antiquities as looting bankrolls terror. The Wall Street Journal. https://www.wsj.com/articles/syrian-monuments-menrace-to-protect-antiquities-as-looting-bankrolls-terror1423615241.

[11] Poria, Y., Butler, R., Airey, D. (2001). Clarifying heritage tourism. Annals of Tourism Research, 28(4): 1047-1049. 7383(00)00069-4

[12] Khovanova-Rubicondo, K. (2010). Impact of European cultural routes on SMEs' innovation and competitiveness. Council of Europe, pp. 1-261.

[13] About the Cultural Routes of the Council of Europe, Council of Europe. https://www.coe.int/en/web/culturalroutes/about, accessed on Jul. 11, 2019.

[14] Robinson, M., Picard, D. (2006). Tourism, culture and sustainable development. UNESCO: Paris, pp. 1-95.

[15] Richards, G., Wilson, J. (2006). Developing creativity in tourist experiences: A solution to the serial reproduction of culture? Tourism Management, 27: 1209-1223. https://doi.org/10.1016/j.tourman.2005.06.002

[16] Richards, G. (2000). Tourism and the world of culture and heritage. Tourism Recreation Research, 25(1): 9-17. https://doi.org/10.1080/02508281.2000.11014896

[17] Richards, G., Raymond, C. (2000). Creative tourism. Richards and Raymond, 23: 16-20.

[18] Callot, P. (2013). Slow tourism. Encyclopedia of Corporate Social Responsibility, 2156-2160. https://doi.org/10.1007/978-3-642-28036-8_149

[19] Wurzburger, R., Aageson, T., Pattakos, A., Pratt, S. (2009). Creative Tourism, a Global Conversation. Sunstone Press, New Mexico, 87-89.

[20] Shishmanova, M.V. (2015). Cultural tourism in cultural corridors, itineraries, areas and cores networked. Procedia - Social and Behavioral Sciences, 188: 246-254. https://doi.org/10.1016/j.sbspro.2015.03.382
[21] Zabbini, E. (2012). Cultural routes and intangible heritage. AlmaTourism, 3(5): 59-80. https://doi.org/10.6092/issn.2036-5195/3188

[22] Melenez, J., Hawkins, Don., Behzadnejad, F. (2015). Multi-country destination development: An opportunity to stimulate tourism in the Americas. World Tourism Organization (UNWTO) - A Specialized Agency of the United Nations, Madrid, pp. 1-53. https://doi.org/10.13140/RG.2.2.11720.62728

[23] Weaver, D.B. (1995). Alternative tourism in Montserrat. Tourism Management, 16(8): 593-604. https://doi.org/10.1016/0261-5177(95)00082-8

[24] Strauss, C.H., Lord, B.E. (2001). Economic impacts of a heritage tourism system. Journal of Retailing and Consumer $\quad$ Services, 8(4): 199-204. https://doi.org/10.1016/S0969-6989(00)00023-0

[25] Majdoub, W. (2010). Analyzing cultural routes from a multidimensional perspective. AlmaTourism, 1(2): 2937. https://doi.org/10.6092/issn.2036-5195/2029

[26] Dayoub, B., Yang, P., Dayoub, A., Barakat, T., Li, H. (2018). Tourism and strategic planning: learning from the Chinese province of Hainan to improve the Syrian coastal region. WIT Transactions on Ecology and the Environment, 217: 535-556. https://doi.org/10.2495/SDP180471

[27] Syrian Arab Republic - Ministry of State for Environment Affairs, National Report of the Syrian Arab Republic. Proceedings of the United Nations Conference on Sustainable Development (Rio+20), pp. 1-46. https://sustainabledevelopment.un.org/content/documen ts/982syria.pdf, accessed on Jan. 28, 2018.

[28] Trono, A., Oliva, L. (2017). Cultural tourism and historical routes. The way of St Peter from Jerusalem to Rome. Methaodos. Revista de Ciencias Sociales, 5(1): 10-29. http://dx.doi.org/10.17502/m.rcs.v5i1.152

[29] Pattanaro, G., Pistocchi, F. (2016). Linking destinations through sustainable cultural routes. Emerging Issues in Management, (1): 83-96. http://dx.doi.org/10.4468/2016.1.08pattanaro.pistocchi

[30] Eisenhardt, K.M. (1989). Building theories from case study research. The Academy of Management Review, 14(4): 532. https://doi.org/10.2307/258557

[31] Csapo, J., Berki, M. (2008). Existing and future tourism potential and the geographical basis of thematic routes in south Transdanubia, Hungary. Proceedings of 6th annual International Conference of Territorial Intelligence caENTI, pp. 1-10.

[32] Morgan, J.Q., Lambe, W., Freyer, A. (2009). Homegrown responses to economic uncertainty in rural America. Rural Realities, 3(2): 1-15.

[33] Briedenhann, J., Wickens, E. (2004). Tourism routes as a tool for the economic development of rural areasvibrant hope or impossible dream? Tourism Management, 25(1): $\quad 71-79 . \quad$ https://doi.org/10.1016/S02615177(03)00063-3

[34] Craik, J. (2002). The Culture of Tourism, Touring Cultures: Transformations of Travel and Theory. Routledge, London, 123-146.

[35] Cultural Routes and Itineraries, World Tourism Organization (UNWTO) - Agencia de Turismo de las Islas Baleares (ATB): Madrid, pp. 1-146. https://catedratim.files.wordpress.com/2017/01/omt2015-global_report_cultural_routes_itineraries.pdf, accessed on Jun. 22, 2018. 
[36] Fernández, M.I.L. (2006). Diseño y programación de itinerarios culturales. PH Boletín del Instituto Andaluz del Patrimonio Histórico, 14(60): 20-33. https://dialnet.unirioja.es/servlet/articulo? codigo $=21638$ 34

[37] Díez Santo, D. (2011). Strategic planning in inland tourism areas: Keys for the design and formulation of competitive strategies. Investigaciones Turísticas, 1: 6992. https://doi.org/10.14198/INTURI2011.1.05

[38] Miguéns, J., Baggio, R., Costa, C. (2008). Social media and tourism destinations: TripAdvisor case study. Proceedings of the IASK International Conference on 'Advances in Tourism Research', pp. 194-199.

[39] Buhalis, D., Law, R. (2008). Progress in information technology and tourism management: 20 years on and 10 years after the internet-the state of ETourism research. Tourism Management, 29(4): 609-623. https://doi.org/10.1016/j.tourman.2008.01.005

[40] Pourabedine, Z., Nourizadeh, A., Hosseini, S. (2011). Heritage tourism website evaluation framework. Proceedings of the International Conference on Management (ICM), pp. 625-630.

[41] Ceron, J.P., Dubois, G. (2003). Tourism and sustainable development indicators: The gap between theoretical demands and practical achievements. Current Issues in Tourism, 6(1): 54-75. https://doi.org/10.1080/13683500308667944

[42] Addis, C. (2018). 4 Protestant Reformation \& America, History Hub. http://sites.austincc.edu/caddis/protestantreformation-america/, accessed on Oct. 19, 2018.

[43] Abraham Path: Can Tourism Alleviate Poverty and Boost Shared Prosperity? The World Bank, 2014. http://www.worldbank.org/en/news/feature/2014/06/19/ can-tourism-alleviate-poverty-and-boost-sharedprosperity, accessed on Jan. 16, 2016.

[44] Leary, K., Sebenius, J.K., Weiss, J. (2009). Negotiating the path of Abraham. Harvard Business School, Boston, $1-41$.

[45] Lerwill, B. (2014). Cover story: 10 of the best new walking trails. APL Media Limited. http://www.natgeotraveller.co.uk/smart-

travel/features/cover-story-10-of-the-best-new-walkingtrails/, accessed on Feb. 24, 2016.

[46] Havel, V. (2016). Our Story, Abraham Path Initiative. https://www.abrahampath.org/about-us/our-story/\#, accessed on Jan.16, 2016.

[47] Ghifari, A.A. (2018). Journey of Ahlul Bayt to Kufa and damascus. A Probe into the History of Ashura, Islamic Seminary Publications.

[48] Arrival of Ahle Bait a.s in Yazid's Castle, Shaheed Foundation

Pakistan. http://www.shaheedfoundation.org/Articles.asp?Id=97, accessed on Oct. 20, 2018.

[49] Janabe Zainab (s.a.) and Her Journey from Karbala to Syria, $\quad$ Al $\quad$ Muntazar 2015. https://www.almuntazar.com/1931/janabe-zainab-s-aand-her-journey-from-karbala-to-syria/, accessed on Oct. 20, 2018

[50] Rahim, B.H. (2018). Journey of Ahlul Bayt of Imam Husayn (A.S.) from Karbala to Madinah, Imam Reza (A.S.)

Networ. https://www.imamreza.net/old/eng/imamreza.php?id=9 061, accessed on Oct. 19, 2018.

[51] Hajj, The British Museum 2017. https://smarthistory.org/hajj/, accessed on Oct. 20, 2018.

[52] Bigg, M. (2018). The Ottoman Route (Istanbul Damascus - Mecca), Rustees of the British Museum. http://www.britishmuseum.org/explore/themes/hajj/the journey/routes/the_ottoman_route.aspx, accessed on Oct. $18,2018$.

[53] Campolo, D., Bombino, G., Meduri, T. (2016). Cultural landscape and cultural routes: infrastructure role and indigenous knowledge for a sustainable development of inland areas. Procedia - Social and Behavioral Sciences, 223:

576-582. https://doi.org/10.1016/j.sbspro.2016.05.350

[54] Syrian Arab Republic, UNESCO World Heritage Centre. http://whc.unesco.org/en/statesparties/sy, accessed on Sep. 14, 2018.

[55] Arslan, M. (2013). Ancient routes, new destinations: Roman road via Sebaste as a thematic cultural route. Mediterranean Journal of Social Sciences, 4(10): 660665. https://doi.org/10.5901/mjss.2013.v4n10p660

[56] Ridenour, S. (2014). Among Almond Blossoms and Olive Groves on the Abraham Path: How Hiking in Palestine Creates Jobs for Women and Youth, World Bank Group. https://blogs.worldbank.org/arabvoices/among-almondblossoms-and-olive-groves-abraham-path, accessed on Oct. 24, 2018.

[57] Chan, T.W., Goldthorpe, J.H. (2007). Social stratification and cultural consumption: The visual arts in England. Poetics, 35(2-3): 168-190. https://doi.org/10.1016/j.poetic.2007.05.002

[58] Rizzo, L.S., Rizzo, R.G., Trono, A. (2013). Religious itineraries as the driving forces behind sustainable local development in the Veneto? Towards a proposal for promoting an unusual and often 'Subliminal' form of Heritage: Sanctuaries and minor churches. Journal of Tourism, Culture and Territorial Development, 4(7): 5992. https://doi.org/10.6092/issn.2036-5195/3909

[59] Csi, C. (2015). Cultural routes management: from theory to practice. Step-by-Step Guide to the Council of Europe Cultural Routes, Council of Europe, Strasbourg. 